\title{
Human Rights and Minority Languages: Immigrants' Perspectives in Greece
}

\author{
Argyro-Maria Skourmalla ${ }^{1} \&$ Marina Sounoglou ${ }^{2}$ \\ ${ }^{1} \mathrm{PhD}$ doctorate candidate, Faculty of Humanities, Education and Social Sciences at the University of Luxembourg, \\ Luxembourg \\ ${ }^{2}$ Adjunct Faculty of the Hellenic Open University, Greece \\ Correspondence: Argyro-Maria Skourmalla, PhD doctorate candidate, Faculty of Humanities, Education and Social \\ Sciences at the University of Luxembourg, Luxembourg
}

\author{
Received: November 22, 2020 Accepted: December 30, $2020 \quad$ Online Published: February 6, 2021 \\ doi:10.5539/res.v13n1p55 \\ URL: https://doi.org/10.5539/res.v13n1p55
}

\begin{abstract}
Human rights and their fortification through conventions and treaties are thought to be one of the greatest achievements of the previous century. A very important category of human rights is the Linguistic Human Rights (LHR). Linguistic Human Rights are connected to basic human rights and are of great importance in policy and planning. There have been numerous researches on language policies and in educational systems around the world. However, minority populations' opinion, for example refugees' opinion, is rarely represented in these researches. The present research aims at exploring the existing language policies in Greece in reference to minority languages. For the needs of this research six adult refugees participated in short semi-structured interviews. Even though participants seemed to be unaware of the term "Linguistic Human Rights", most of them referred to the difficulty they have in exercising major human rights due to the monolingual policies that are followed in Greece. Taking into consideration the importance of Linguistic Human Rights and people's need to use their mother language(s) in Greece, the last part of this research includes suggestions and ideas towards multilingual practices that come from different countries around the world.
\end{abstract}

Keywords: human rights, linguistic human rights, language policies, language planning, educational policies

\section{Introduction}

Human rights represent the set of ethical principles that determine human behavior. Human rights have been closely linked to immigrants ${ }^{1}$ for centuries. Amongst human rights, language rights -or else said linguistic rights- is a very important category. Language rights are mentioned in the Articles of multiple international Conventions and Treaties since they are thought to influence human rights in all levels. The term that describes the connection between linguistic rights and human rights is Linguistic Human Rights (LHR). In general, LHR refer to the language rights that are "basic for a dignified life" (Skutnabb-Kangas, 2008, p. 109) and are connected to rights such as the right to quality education, the right to learn a foreign language, etc.

Human rights as well as language rights are of particular importance for minority languages and for their speakers. According to Allardt (1984), it is difficult to define a minority language because languages "cannot be distinguished on purely linguistic criteria" (p. 195). However, there have been numerous efforts to define the term. According to Grenoble and Singerman (2017) a minority language is a language that is spoken by "less than 50 percent of a population in a given region, state or country" (p. 1). The official definition for minority languages given by the Council of Europe in the European Charter for Regional and Minority Languages (ECRML, 1992) rerefers to "languages traditionally used within a territory of a state by nationals of that state who form a group numerically smaller than the rest of the state's population; they are different from the official language(s) of the state" (p. 1-2). Moreover, the recognition of a language as a minority language "implies that this language can claim certain rights, which are laid down in the form of laws" (Van Dongera, Van der Meer \& Sterk, 2017, p. 11). This means that minority languages depend on both the number of

\footnotetext{
1 According to the International Organization of Migration an immigrant is a person who decides to move to country, other than the country of his/her origin or "the country of usual residence" (IOM, 2019, p. 101) for reasons other than holiday, business, medical treatment, etc.
} 
speakers of this language in a given territory and the legal status of this language in regards to the state's policies.

However, a "human rights deficit" (Kjaerum, 2005, p. 51) and a "deficit thinking" (McNelly, 2015, p. 6) has been observed amongst European countries. Kjaerum (2005) explains that the increasing human flows towards European countries have increased fear and "xenophobia" which have resulted to stricter policies and to the strengthening of "control mechanisms" (p. 51). According to McNelly (2015), the fear that the increased number of immigrants has caused, has also affected the view on immigrants' languages. More specifically, the existence of multiple languages in a region is considered to contribute to affect in a negative way the unity and the cohesion between people in this region. That explains why immigrants are often blamed for "slowing national development and being a barrier to the dominant culture" (UN New Centre, 2013 in McNelly, 2015, p. 6).

This is also the case in Greece. The increasing number of immigrants who arrive in Greece has been a challenge in many levels. The result was the anxiety for possible negative consequences that the arrival of immigrants might cause to the host country as well as the "fear that the distinctiveness of the national culture and identity might be blurred because of the influx of large numbers of foreigners" (Triandafyllidou, 2000, p. 187). This xenophobic tendency led to strict monolingual policies that favor the dominant language and culture and add to the marginalization of immigrants.

Fear and xenophobia towards immigrant populations has in many cases contributed to actions that indicate that "not all languages are valued equally" (Ochs \& Schieffelin, 1995, p. 50). In fact, in spite of the $25^{\text {th }}$ Article in the Refugee Convention, there are cases in which immigrants' mother languages have become an obstacle to individual's access in the host country. That is the case with the twenty-eight immigrants from Africa whose application for asylum in Greece were rejected due to language barrier and with the excuse of the lack of a translator. Language rights in regards to the asylum confirm the vulnerability of this population and will be analyzed in detail in this text.

In general immigrants are usually characterized as "vulnerable population". Anagnostou and Gioni (2015) explain that the term "vulnerable population" refers to groups of people who experience greater risk of poverty and social exclusion compared to the general population. Moreover, vulnerability is closely related to this group's reduced ability to deal with or to resist to the conditions which may lead it to social exclusion (Anagnostou \& Gioni, 2015). According to Derose, Escarce and Lurie (2007) the vulnerability of a group of people is shaped based on "political and social marginalization and a lack of socioeconomic and societal resources" (p. 1238).

Immigrants, between other groups of people are likely to be considered as vulnerable population with language being one of the main factors that contribute to the vulnerability of this group of people. However, it is important to mention that vulnerability of a population depends on the specific sociopolitical and economical context. In general, monolingual policies have a "very strong assimilationist goal" (McNelly, 2015, p. 7) forcing people to leave special characteristics, such as their language(s), behind. This means that monolingual policies prevent immigrants from having "an equal footing with the majority members" (McNelly, 2015, p. 8) whilst their participation in social domains and in public services in the host country is reduced.

The present research aims to explore the existing language policies in Greece from immigrants' perspective, as vulnerable population. In general, scholars support that political representation can only be examined in groups of people. People who have similar interests and needs form "communities of interest" (Williams, 1998, p. 25) that constitute the represented for the governments.

\section{The Case of Greece}

Greece is a small Balkan country that is located in the southeast part of Europe. Greece became member of the Council of Europe in 1949 and signed the "European Convention on Human Rights" in 1974. Greece's membership in the Council of Europe means that Greece has agreed to adapt national official laws and regulations in order to apply human rights as described in the Convention signed.

The last census which was executed in 2011 indicated that from 2006 to 2011 more than 200.000 people with a citizenship other than Greek moved to Greece. Based on the official document of the Greek Statistical Authority, these people came from Albania, Romania, Bulgaria, Pakistan, Afghanistan, Cyprus, United Kingdom, Germany, Egypt, India, Georgia, Bangladesh, United States of America, Italy, Russia, France, Poland, etc.

The previous number has dramatically increased with the arrival of immigrants the last six years. According to the Asylum Service the past five years more than one million asylum seekers arrived in Greece. To this number 74.482 asylum seekers who arrived in Greece in 2019 through land and sea are added (UNCHR, 2019). According to UNCHR's (2019) statistics immigrants who arrived in Greece mostly came from Afghanistan, Syria, Iraq, Iran, State of Palestine, Kuwait, Algeria, Dominican Republic of Congo, etc.

However, the Greek report for human rights for the year 2019 focused on refugees and to the country's "failure to protect their rights". More specifically the report mentioned "deficiencies in the reception and asylum system", 
"unsanitary, unhygienic conditions, and lack of sufficient specialized care, including medical care, trauma counseling, and psychosocial support", "physical and gender-based violence", failure "to resolve a shortage of juvenile shelters or foster care", violations in unaccompanied children's protection and limited access to "essential services" (Human Rights Watch, 2019).

The above information on Greece's sociopolitical context was mentioned as additional information that will contribute to a better interpretation of the subject according to Kaplan and Baldauf (1997).

\subsection{Language Rights and Citizenship in Greece}

Language rights, as a sub-category of human rights, are closely related to migration. As Piller and Takahashi (2010) explain, this connection between immigrants and human rights "is mediated by language proficiency and communicative competence" (p. 583). In other words, immigrants' language skills influence their access to human rights. Ghandour-Demiri (2017) supports that the languages that an immigrant speaks influences his/her survival in the host country. More specifically, Ghandour-Demiri (2017) mentions that the language(s) the individual speaks determines the "information and services can access" (p. 10). Being able to communicate with people in the host country and to express any needs, depends on the language(s) spoken.

According to the existing framework on human rights, it is states' responsibility to promote and to protect human rights. This means that protection of human rights depends on citizenship. Acquiring citizenship in Greece means that one is provided with a Greek ID and that he/she has the same rights as Greek citizens and as other citizens of the European Union (Refugee.Info, 2018).

One of the most common ways in which a person can acquire Greek citizenship is through naturalization. Naturalization is the term used to describe the administrative act through which a state gives to a non-Greek citizen, Greek citizenship. The process of naturalization is described in detail in the Greek Citizenship Code $^{2}$. Between the requirements and the obligations that must be fulfilled by individuals who apply for the Greek citizenship, knowledge of the Greek language is a perquisite. More specifically, according to the fifth Article of the Greek Citizenship Code, in order to get the citizenship applicants must know the Greek language. The naturalization process includes an interview with a Commission at which the applicant is asked to present evidence that proves the knowledge of the Greek language. During this interview, the applicant is also evaluated in terms of his/her verbal and writing skills in the Greek language.

The second case for obtaining citizenship is through recognition of refugee status. Each state has its own policies in regards to asylum procedures. The procedure followed by Greece is described in detail by the Ministry of Migration and Asylum $^{3}$. The law regarding the asylum procedure that is now in force in Greece is the law 4636/2019 . The personal interview remains a very important part of the asylum's procedure mainly because the personal interview is, in many cases, seen as proof for the refugee status (Marouda \& Saranti, 2020). Details of the personal interviews that refer to the confidentiality, the preparation time, the gender of the interviewee and the interviewer, as well as other information about the personal interviews are described in detail in the seventy-seventh Article of the aforementioned law.

In personal interviews language remains a very important issue. According to the sixty ninth Article of the 4636/2019 law, the applicant has the right to have an interpreter during the personal interview provided that the necessary communication cannot be obtained without the interpreter. The services of the interpreter can even be provided by distance. The role of the interpreter is explained in the same Article of this law. More specifically, the interpreter must be able to ensure the necessary communication in order for the applicant to give information on his/her personal story and to help him/her confirm the reasons for which he/she should gain asylum.

Except of the personal interview, the twenty fifth Article of the Refugee Convention ${ }^{5}$ (1951) states that applicants have the corresponding authority is obliged to provide the asylum seeker with documents that are translated to the applicant's mother language, in order to be understandable. In addition to that, the 4636/2019 law states that applicants are informed for the response to their application in a language that they understand.

The above regulations bring languages to the fore. From the above it results that it is very important for applicants to be able to participate in the procedures in their mother languages, or with a language with which they are familiar. This means that authorities are obliged to overcome the language barrier. As a result, applicants' languages are valued and that the individual can actively participate in the procedure.

\footnotetext{
${ }^{2}$ https://www.ypes.gr/en/acquisition-of-the-greek-citizenship-sup-doc/

${ }^{3} \mathrm{http} / / /$ asylo.gov.gr/?page_id=107

${ }^{4}$ https://www.e-nomothesia.gr/kat-allodapoi/prosphuges-politiko-asulo/nomos-4636-2019-phek-169a-1-11-2019.html

${ }^{5}$ https://www.refworld.org/pdfid/53e1dd114.pdf
} 
Research shows that the vast majority would prefer to receive information in their mother language(s) (Ghandour-Demiri, 2017). However, as far as minority languages in Greece are concerned, data shows that speakers of minority languages in Greece receive insufficient information due to lack of interpreters and cultural mediators (Ghandour-Demiri, 2017). Ghandour-Demiri (2017) explains that languages and information dissemination in a language that is understandable to arriving populations, are considered to be one of the "most challenging humanitarian tasks" (p. 33) nowadays.

Before moving to the main part of the present research and having in mind the above Articles and laws considering the language issue in regards to citizenship and immigrants, it is important to briefly refer to the broader story of language rights in Greece.

\subsection{Language Rights and Linguistic Human Rights in Greece}

Languages in Greece became a central issue before the Greek Revolution of 1821. For many decades all language policies and planning in Greece were about the issue of diglossia (Dendrinos, 2007). The issue started with the question for the establishment of a national language that would represent the Greek nation and that would strengthen the national consciousness during the Revolution (Dendrinos, 2007). At that time the debate was between a traditional and a more liberal view of the Greek languages.

The debate about choosing the official language for the Greek state came back towards the end of the nineteenth century as more of an ideological issue. Moreover, after the first World War, it became visible that the linguistic debate had a negative impact on education. More intellectuals and scholars supported the establishment of the spoken variety of the Greek language as a means towards progress. The use of a linguistic variety in education which was different than the variety spoken seemed to be "the source of evil in education" (Dendrinos, 2007, p. 55) and prevented people from education.

The linguistic debate continued and the language policies varied based on the governments. The debate ended in 1976 with the fall of the dictatorship when the spoken variety of the Greek language was voted as the official form of language. This means that the previous decades people had limited access to education. Since the use of language indicated the individual's social class people of the lower social classes were marginalized and, in a way, excluded from participating in social issues.

This linguistic debate was also challenged with the addition of Northern province to the Greek state. The population who lived in those territories spoke different languages and did not have Greek as their mother language (Tsioumis, 2014). In spite of the different mother languages, the language policies of the time insisted on the cultural and linguistic homogenization with the ultimate goal of assimilation of this population. As a result, Greek became the language of instruction with a special focus on the instruction of the language from kindergarten.

The language issue changed with the arrival of population from Turkey in the early twentieth century (Dendrinos \& Theodoropoulou, 2008). The heterogeneous group of people that kept arriving in Greece caused numerous reactions. The year 1923 is considered to be very important for two reasons because except of the arrival of refugees from Turkey, it was the year when United Nations talked about educational issues that referred to minorities. Despite of that, language policies insisted on the assimilation of minority population and on the teaching of the Greek language to all non-native speakers.

Throughout these years, education and the teaching of the Greek language remained a great challenge, especially for minority populations. After the Second World War, inspectors observed with disappointment that there was still a large number of students who spoke other languages as mother languages (Tsioumis, 2014). This resulted to a continuation of the assimilative policies that were expected to eliminate minority languages and their cultures.

In general, linguistic policies towards minorities indicated that the Greek state did not fully recognize the existing minorities in the country. The exception to that is the Turkish language in the region of Thrace where the Muslim minority lives. The basis for the case of Thrace was the Lausanne treaty $(1923)^{6}$ which fully protects educational and linguistic rights of the minority. More specifically, the Lausanne treaty abides Greece to provide public education in Turkish which is students' mother language. Following the Lausanne treaty, the Greek state typically recognized the educational and the linguistic rights of Thrace's minority. As a result, the education of this population was seen as

\footnotetext{
6 According to the 40th Article of the treaty "Turkish nationals belonging to non-Moslem minorities shall enjoy the same treatment and security in law and in fact as other Turkish nationals. In particular, they shall have an equal right to establish, manage and control at their own expense, any charitable, religious and social institutions, any schools and other establishments for instruction and education, with the right to use their own language and to exercise their own religion freely therein".
} 
education of a group of people which is outside of the Greek state with the Turkish government being responsible for the education of these people (Tsioumis, 2014). At this point it is important to mention that the Turkish minority of Thrace was the only minority that was officially recognized and the policies that the Greek government applied referred to this population.

An important change took place the decade of 1980 when the Greek government decided to take measures towards the "'hellenization' of minority education" (Tsioumis, 2014, p. 669). The next decade was accompanied with an effort to rationalize things between the Greek state and the Turkish minority. The most important measure was the regulation that gave to a small percentage of the Turkish minority students the possibility to study at a Greek University (Tsioumis, 2014).

Together with that, scholars' interest increased and research projects for the education of the Turkish minority population were conducted. These projects were accompanied with measures that had already been applied in Europe and with major reforms in the public schools, such as the establishment of the Intercultural schools.

However, there has been strong criticism to these projects and reforms that were considered to continue the assimilative policy (Gropas \& Triantafyllidou, 2011) of the past. Despite of that, all these initiatives did not seem to differentiate the monolingual reality neither in regards to the educational system (Tsioumis, 2014) nor to the country. In all this time, except of the minority of Thrace, minority population and minority languages in the Greek territory were not officially recognized. This meant that minority population had limited access to the educational system and limited participation in social domains and in public services due to the language barrier, making this population more vulnerable and marginalized.

Taking the above into consideration, the present research aims to examine language policies and LHR from a minority group's point of view. Having in mind the monolingual policies that were followed in Greece and that contributed to the marginalization of such population during the previous decades the present research's aim is to give voice to a minority group and to examine how they perceive the existing language policies in Greece. This research turns to adult immigrants, which is considered to be a minority group, in order to explore whether the existing language policies in Greece respond to their needs and whether these policies are in accordance to their rights.

\section{Literature Review}

\subsection{The Broader Notion of Human Rights}

"Human rights" is a term that seems to be simple but has a great value for humanity. Human rights represent the set of fundamental rights and freedoms that human are entitled simply because they are human beings. From the moment of our birth, people as human beings, have "inherent" rights (Universal Declaration of Human Rights, 1948) that refer to individual, political, social and economic rights and that are the basis for a dignified and peaceful physical and social existence as a biological, spiritual and social being. In a broader sense, human rights refer to ethical principles and set the basis for human behavior. That is why human rights are legally protected as rights by the national and the international law.

It was after the end of the Second World War that human rights seemed to have reached their lowest point. That was the time when United Nations was created as a global organization that aims to peace and prosperity. Following the aims of the Organization for world peace, United Nations signed the Universal Declaration of Human Rights (UDHR) in 1948. This document which is of great significance for the history of human rights protects fundamental human rights and establishes democratic societies globally.

In order to highlight the importance of human rights and to officially recognize them, the European Union created the "Charter of Fundamental Rights of the European Union"7 or else said the "European Convention on Human Rights"8 (ECHR). This document, which fortifies human rights, aims at reassuring the values and the principles of the European Union in regards to a peaceful future with respect to human beings and to democracy.

Human rights led to the development of numerous treaties and conventions. According to Ritter (2019) all these "treaties do more than just reduce repression, they also increase protest". This means that human rights have a deeper importance. Human rights encourage change, create expectations and give people voice to ask for what they want (Ritter, 2019). Moreover, according to Browne and Donnelly (2013) human rights' aim is to ensure, in a way, "meaningful and effective participation of vulnerable" people.

Even though human rights are universal and refer to all human beings there are groups of people, such as persons with

\footnotetext{
${ }^{7}$ https://www.europarl.europa.eu/charter/pdf/text_en.pdf

8 https://www.echr.coe.int/Documents/Convention_ENG.pdf
} 
disabilities, members of minority groups, migrant workers, women, etc., who are thought to be 'most at risk' as marginalized groups (United Nations, 2014). In the present article emphasis is given on minority language speakers and their language rights, which will be analyzed below.

\subsection{Language Rights}

In the above framework, another very important category of human rights is the language rights or the linguistic rights. Phillipson, Rannut and Skutnabb-Kangas (1994) support that "linguistic rights should be considered basic human rights" (p. 1) since language rights appear, directly or indirectly in all levels of human rights. Kymlicka \& Patten (2003) note that "language rights are concerned with the rules that public institutions adopt with respect to language use in a variety of different domains" (p. 16).

In general, the importance of language rights is confirmed through multiple documents. The first document which includes languages in its Articles is the Charter of the United Nations (1945). In the general principles of the Charter "promoting and encouraging respect for human rights and for fundamental freedoms for all without distinction as to race, sex, language, or religion" (p. 3) are referred. Similar reference is also included in the second Article of the UDHR (1948), with a focus on the non-discriminatory nature of human rights and freedoms. More specifically the Declaration notes that "everyone is entitled to all the rights and freedoms set forth in this Declaration, without distinction of any kind, such as [...] language" (p. 15).

Except of the above, language rights are also mentioned in the following Conventions:

1) Article 6 of the Convention against Discrimination in Education (1960),

2) Articles 4, 14, 24 and 27 of the International Covenant on Civil and Political Rights (1966),

3) Articles 5, 9 and 10 of the Framework Convention for the Protection of National Minorities (1988),

4) Articles 29 and 30 of the Convention on the Rights of the Child. Discrimination in Education (1960),

All the above documents aim at promoting and protecting minority languages and their speakers.

As mentioned above the Charter of the United Nations was the first official document that refers to languages. This document became the basis for other Treaties that focused exclusively on language rights. The Universal Declaration of Linguistic Rights $^{9}$ (1996) is the first such example. This document, which is also known as the Barcelona Declaration, was signed in 1996 by an International Association of writers, the International Pen. The Universal Declaration of Linguistic Rights "takes language communities [...] as its point of departure" (p. 23) and aims "to define the rights of language groups" (p. 23) such as immigrants and refugees.

Another such important document was the European Charter for Regional or Minority Languages (ECRML) which was signed by the Council of Europe in 1992. This document was also created so as to "promote regional or minority languages in order to safeguard them" (ECRML, 1992, p. 3). In general, the importance of minority languages was recognized at the end of the Second World War when minority populations' rights gained attention. It was when minority languages were firstly seen as integral part of global diversity and as an important factor for world peace and stability ${ }^{10}$ (Van Dongera, et al., 2017). Six years after the ECRML, the Framework Convention on the Protection of National Minorities $^{11}$ (FCNM) was signed. The FCNM reassures the "full and effective equality of persons belonging to minorities in all areas of economic, social, political, public and cultural life together with conditions that will allow them to express, preserve and develop their culture, religion, language and traditions (Council of Europe, 2016b)" and "provides guidelines for their (minority) linguistic freedom and rights regarding education" (Van Dongera, et al., 2017, p. 18).

From the above it results that almost all the Declarations and documents which refer to language rights focus on minority languages' rights. According to Skutnabb-Kangas and Phillipson (2017) "linguistic rights are more urgently needed for minorities than for majorities" (p. 457). Their view is based on punishments and on the negative consequences that speakers of minority languages have been through reportedly. The same view is supported by Santos Rovira (2015) who explains that minority languages are confronted with important changes when they are opposed to a national state's language or to other languages that are thought to be inferior in terms of "prestige, social and economic value, and normative notions of usefulness" (p. 163).

More specifically, Gules et al. (1983) support that in order to understand "specific language problems we need to study

\footnotetext{
${ }^{9}$ https://culturalrights.net/descargas/drets_culturals389.pdf

10 "The upheavals of European history have shown that the protection of national minorities is essential to stability, democratic security and peace in this continent" (FCNM, 1998, p. 2).

${ }^{11}$ https://rm.coe.int/16800c10cf
} 
how people react to language varieties spoken in their locale" (p. 81). Indicatively, Catalan in Sardinia (Santos Rovira, 2015), South Asian in Canada (Negpal \& Nicoladis, 2010), are examples of minority languages whose speakers have experienced negative attitudes towards these minority languages or whose speakers were somehow forced to using the majority languages for various reasons, such as of prestige.

Negative attitudes and maltreatments against minority language speakers are also connected to violations of human rights. This kind of violations led to the development of a new category of human rights, the Linguistic Human Rights (LHR).

\subsection{Linguistic Human Rights (LHR)}

Linguistic Human Rights (LHR) were developed as a subcategory of human rights which resulted from the combination of human rights with language rights. This means that LHR do not include all language rights. Skutnabb-Kangas (2000) suggests that in order to identify which rights belong to the LHR one must consider the nature of each right.

In general, LHR are defined as "only those language rights [...] which are so basic for a dignified life that everybody has them because of being human; therefore, in principle no state (or individual) is allowed to violate them" (Skutnabb-Kangas, 2008, p. 109). Despite of the "ongoing skepticism about the recognition of the LHR" (Skutnabb-Kangas \& May, 2017, p. 125) Skutnabb-Kangas and May (2017) support that LHR are of great importance for human rights.

LHR involve human rights in multiple levels. Firstly, languages can be viewed as means of communication and "markers of identity" (Leibowitz, et al., 2005, p. 26). In this sense, as indicated in the European Charter for Regional or Minority Languages, languages themselves are rights. Constitutionally speaking, taking the example of the 30th Article of the United Nations' Convention on the Rights of the Child, LHR can be individual in the sense that they refer to one person at a time. LHR could also be viewed as collective as in the United Nations' Declaration on the Rights of Indigenous People, which refers to a group of people. LHR can also be personal, which means that one person has these rights regardless of the country of residence, territorial, which depend on the country's laws or a combination of these two. It is important to mention that all these categories coexist harmonically in LHR. Overall "linguistic human rights complement the existing human rights framework and there are solid reasons why states should protect them" (Szoszkiewicz, 2017, p. 105).

\subsection{Language Policy and Planning (LPP)}

According to Skutnabb-Kangas (2012) governments' approach towards LHR is part of the state's language planning and policies. In this sense, LHR and their application indicate the state's intention towards each language and towards speakers of each language.

"Language policy" as a term seems to have appeared during the Second World War. This term was firstly coined by Weinreich (1953) in his book "Languages in contact". The term was then enriched by Einar Haugen (1953) in his study around the use of Norwegian in America. Those two scholars started with the practices and the aspects that are associated to language contact. The term then expanded aiming to include the "combination of official decisions and prevailing public practices related to language education and use" (McGroarty, 1997, p. 1). Grin (2000) defines language policy as "a systematic, rational, theory-based effort at the societal level to modify the linguistic environment with a view to increasing aggregate welfare" (p. 7).

The legal dimension of language use was firstly noted by Kloss (1969) as "status planning" which is currently seen in bibliography as "language planning" (LP). Based on Lo Bianco (2010) language planning is the third and the last level of a linguistic problem. Specifically, he mentioned that "a language problem leads to a language policy, which leads to LP (language planning)" (Lo Bianco, 2010, p. 144). There have been numerous efforts for the definition of the term. One of the most used definitions comes from Cooper (1989) who explains that "language planning refers to deliberate efforts to influence the behavior of others with respect to acquisition, structure, or functional allocation of their language codes" (p. 45).

Policies relevant to language are described with the term "language policy". Language policy refers to issues that are relevant to languages, language learning and language teaching. Language policy is also involved with the broader language needs of each state's society (Wiley, 2015). Taking these into account, society is expected to have a major impact on language policy and to influence the corresponding decisions.

There has been observed a frequent confusion between the terms "language policy" and "language planning". According to Haugen (1959, in Larsen-Freeman, 2018) language planning includes the legal background and the set of ideologies that affects decision making in policies relevant to languages. In other words, language planning describes the specific way in which governmental decisions about languages are made. 
The answer to the previous confusion came from scholars who introduced the term LPP as a "large-scale national planning, usually undertaken by governments, meant to influence, if not change, ways of speaking or literacy practices within a society" (Baldauf, 2006, p. 147). Fettes (1997) was one of the scholars who insisted on the connection between language planning and language policy and introduced the field of Language Policy and Planning. According to him "language planning [...] must be linked to the critical evaluation of language policy: the former providing standards of rationality and effectiveness, the latter testing these ideas against actual practice in order to promote the development of better [...] language planning models. "Such a field would be better described as language policy and planning" (Fettes, 1997, p. 14). Since then LPP has constituted "one of the fastest growing subdisciplines of applied linguistics" (Hult \& Johnson, 2015, in Goundar, 2017, p. 81).

In general, LPP refers to a set of governmental decisions; it is to a great extent, a political and a dynamic praxis that needs to be continuously evaluated and open to modifications (Wiley, 2015) aiming at world peace and respect of human ideals (Russak, 2016). This means that LPP is are a matter of power and reflects governments' perceptions towards languages and their speakers. David et al. (2009) explained that one of the main "man-made factors that can cause language shift and death is language policies" (p. 79). And as Terdiman (1985) says "language is always engaged with the realities of power" (p. 85) and is a "basis for distinctions among social groups" (Tollefson, 1991, p. 16). As far as minority languages are concerned, LPP influence state's policies in regards to minority languages but also indicate the government's attitudes towards minority languages and their speakers.

In practice, LPP follows a top-down approach (Yong, Poh Mei \& Zhi Xin, 2016) and refers to the choices that governments make in regards to official and national language(s). In fact, LPP represents "the deliberate effort to influence the function, structure or acquisition of a language within a speech community" (Nkopuruk, 2018, p. 1). All the above call for a holistic examination and justifies why policies should be examined in relation to the social, economic and political context of a state (Kaplan \& Baldauf, 1997).

\section{Methodology}

\subsection{Participants}

For the needs of this research six adult immigrants who come from Syria and from Pakistan and live in Athens participated in short semi-structured interviews with the researcher.

The first step in finding the possible participants was to contact some non-formal educational settings and their teachers. The next step included the approval of two non-formal educational settings and the researcher's visit in these settings. During the visits, learners were informed about the aims of the research and the profile of the researcher by the researcher and their teachers. In total, fourteen learners were informed. Twelve of them showed additional interest for the research. However, in the end six of them signed the consent form and agreed to participate. Four of the learners who did not participate in this research expressed their hesitation towards language. More specifically, these four learners mentioned that they do not speak English and that their level of Greek is not this good in order to participate in a research. The other two learners who refused to participate seemed hesitant towards the recording of the interview and towards signing a consent form.

As mentioned above, six adult immigrants participated in this research (M1, M2, M3, M4, M5, M6). Five of the participants were men (M1, M2, M3, M4, M5) and one of them was a woman (M6). Participants were between 27 and 34 years old. They have all been in Greece from two to eight years and they have all attended Greek language lessons in non-formal educational settings. Two of the participants come from Syria and four of the participants come from Pakistan. All of the participants have prior schooling since they have all been to school in their home countries. Three of the participants have attended University in their home countries but just one of them has graduated University. Another common element between participants is that they speak many languages. More specifically, the languages mentioned by participants were: Turkish, English, French, Urdu, Hindi, Banjabi, Spanish, Swedish and Greek.

As far as Greek is concerned, participants attended courses in different levels of the Greek language. In both non-educational settings, classes are divided based on the Common European Framework of Reference for languages (CEFR). This practically means that classes start from level A1 and go until the level C2 of the Greek language. Based on the two settings' division of language levels, M2 and M3 attend the A2 language level, M4 and M5 attend the A1 language level and M1 attends the B2 language level. At this point it is interesting to mention that even though, according to her teacher, M6 should attend courses of C1 language level, due to the lack of other learners M6 started the academic year, before leaving the country, with learners of the $\mathrm{B} 2$ language level.

\subsection{Research Method}

The present research focuses on qualitative data that derive from open ended interviews or else said, semi-structured interviews. The corpus of questions designed focused on participants' origin and spoken languages, point of view for 
language policies and language rights in Greece. Semi-structured interviews were conducted in person, with each participant separately. Participants were the ones who suggested the date and the time of the interview and they also chose the place where the interviews would be executed.

Interviews were executed in October 2019 and lasted from ten to twenty minutes depending on each participant. All interviews were recorded with the use of the researcher's mobile phone. In each interview, participants were informed about the identity of the researcher and about the main research questions and objectives. Moreover, participants were free to use Greek or English. Participants were also told that they could use their mother language(s). In this last case they were asked to come with a friend of theirs who would have the role of a language translator. The six participants used the Greek language during the interviews and two of them used some words in English.

\subsection{Data Analysis}

Data was analyzed based on the thematic analysis method. Maguire and Delahunt (2017) define the thematic analysis method as a "process of identifying patterns or themes within qualitative data" (p. 3352). Thematic analysis method is thought to be one of the most appropriate analysis methods in social science and aims at an "objective, systematic and quantitative description of the apparent written or oral data" (Berelson, 1952, p. 18).

Even though thematic analysis can be done in various ways (Alhojailan, 2012; Javadi \& Zarea, 2016) this method analysis' goal is to identify and to interpret patterns that emerge from the data and that are relevant to the issue that is being examined. Patterns, or else said themes, refer to elements (e.g. keywords, phrases, meanings) that are identified in different parts of the data and that help the researcher concentrate on some major meanings (Sarafidou, 2011). Thematic analysis is a combination of principals and characteristics from different theoretical frameworks (Maguire \& Delahunt, 2017). The diverse background of thematic analysis makes this specific methodology more flexible and thus suitable for qualitative researches.

In order to respond to the challenges of this qualitative research, the thematic analysis methodology was applied. Data from the semi-structured interviews, led to the emergence of some patterns which were interpreted based on this research's objectives. Findings are presented and further analyzed below.

\section{Findings}

In order to respond to the challenges of this qualitative research, the thematic analysis methodology was applied. Part of what participants said during the interviews were translated in English by the researcher and appear in this section in quotation marks. Data from the semi-structured interviews, led to the emergence of the following themes, or else said patterns, which were interpreted based on this research's objectives.

Table 1. The themes that emerged from the interviews

\begin{tabular}{|ll|}
\hline \multicolumn{1}{|c|}{ Themes that emerged from the interviews } \\
\hline 1. & Languages spoken and use of each language \\
\hline 2. & Languages and prior schooling experience \\
\hline 3. & Participants' view about languages \\
\hline 4. & Language Rights \\
\hline 5. & Linguistic Human Rights and the use of mother languages in Greece \\
\hline 6. & Suggestions on Linguistic Human Rights \\
\hline
\end{tabular}

\subsubsection{Language Spoken and Use of Each Language}

To begin with, as mentioned above, M1 and M6 come from Syria and M2, M3, M4 and M5 come from Pakistan. This means that M1 and M6 have Arabic as mother language and M2, M3, M4 and M5 speak Urdu, Hindi and Panjabi. M2 mentioned that Urdu and Panjabi are the same languages. As far as Urdu and Hindi are concerned M5 explained that these two languages are the same languages but appear with different names.

Except of their mother languages participants speak seven other languages. M1 speaks Turkish, English, French and Greek. M2 mentioned that he speaks Greek but he does not know English very well. M3 mentioned that he speaks Greek, he knows a few English and he is currently taking Spanish courses. M4 speaks French and Turkish and M6 speaks Swedish, English, Arabic and Greek.

When it comes to the use of each language M1 mentioned that he uses Greek at work and he uses Arabic to 
communicate with his family and friends. It is also important to mention that even though M1 said that from all four languages he speaks, in Greece he only uses Greek and Arabic, he used English words during the interview ("snipper", "yeah yeah", “embassy", “trainer").

To the same question M2 answered that in Greece he mostly speaks in Greek. As far as the other languages are concerned, M2 mentioned that he uses Urdu only with people who come from Pakistan and he also uses Urdu in case that someone is from Pakistan and he/she does not know any Greek. As far as English is concerned M2 mentioned that he only uses this language to talk to 'foreigners' who want to speak in English. When asked if he would like to speak more in Urdu in Greece M2 hesitated at first but responded that he wants to speak in Greek in order to learn the language.

Just like M1, M3 mentioned that he uses Greek all day at his job. M3 sells fruit and vegetables in urban markets and he uses the Greek language in order to communicate with customers. As far as the other languages are concerned M3 uses Urdu with his friends but more specifically he prefers to speak Panjabi with them since this is the language that they use to communicate with each other.

To the same direction, M4 answered that he mostly speaks Greek when he is outside. He also mentioned that at work he has to speak in Greek because everyone speaks in Greek. In contrary, M4 uses the Pakistan language in order to talk to friends. However, M4 stressed that even when he is outside with his friends they all choose to speak in Greek because this is what they want to do and because they think that talking in Greek when they are outside the house can help them improve their Greek.

Greek is the language that M5 uses at his work, too. As far as Urdu is concerned M5 supported that even though his friends also speak Urdu he mostly prefers to use the Greek language with them, too. M5 also mentioned that he uses the English language only when he is obliged to do so; he uses English with people with who he cannot communicate in any other language.

To this question M6 answered that when she first came in Greece and she did not know Greek she used the Arabic language. Then, she explained that as soon as she could express herself in Greek she felt free and she chose to speak in Greek. She also mentioned that nowadays, even though she has recently moved to Sweden, she prefers to speak in Greek with her brother and with some of her friends, she listens to Greek music and radio and she sometimes watches Greek series on television.

\subsubsection{Languages and Prior Schooling Experience}

The second theme that emerged from the interviews was participants' language education and prior schooling experience. This theme includes participants' answers about their prior schooling experience and the languages they were taught in schools in their home country. M1 was one of the three participants who attended University. M1 was student at the Law and Gymnastics University but had to interrupt his studies because he left the country. According to him the official language taught in schools in Syria was Arabic. Except of the Arabic language it was compulsory for students in Syria to learn Russian, English and French both at school and at the University. In fact, M1 mentioned that the Russian language was taught at school for military reasons. More specifically, it was compulsory that every Syrian who learnt Russian would help the Russian army.

The second participant, M2, comes from Pakistan and has been to school there. According to him students were taught Urdu and English at public schools. In fact, he mentioned that English is a compulsory school subject and all students learn to read and write in English. He also mentioned that nowadays books in Pakistani schools are in English in contrary to previous years when books were in Urdu.

The third participant, just like the second participant, comes from Pakistan and has not been to University. M3 mentioned that students were taught English and Urdu at public schools. As far as Panjabi is concerned he explained that this language is a spoken variety of the official language and that is why students were taught Urdu not Panjabi.

The next participant is M4 and he comes from Pakistan. M4 finished school and went to the University of Economics but he did not complete his studies. M4 mentioned that the public school all subjects were taught in the Pakistan language and that students could also choose to learn another language between Urdu, French, English, German, Italian, Spanish, Arabic and other languages. From these languages M4 mentioned that he chose Urdu and English, the same two languages that he kept learning at University. The same languages were mentioned by M5. The fifth participant went to school until the fifth grade and mentioned that when he was a student he only learned Urdu and English.

The last participant, the woman who comes from Syria, graduated University and worked in Syria for two to three years before she came in Greece. M6 mentioned that Arabic was the only language taught in primary school and that at junior high school she started to learn some English. As she explained English was a compulsory school subject, just like mathematics, and that they were taught English for five to six hours per week. 


\subsubsection{Participants' View About Languages}

The third theme that emerged from the interviews was participants' views on language. M1 mentioned that he likes Greek and he believes that even though Greece is the best country in Europe, people do not have a chance of finding a good job and of making money. In contrary to Greece, M1 believes that in Arabic countries like Saudi Arabia, Lebanon and Turkey, language is money and that language is only used for making money and for doing business.

Despite of his view about his mother language in the Arabic countries, M1 supported that it would be good for Greeks to learn Arabic and that learning a language in general is useful. According to him knowing a language should be like a race at which the person who speaks the most languages would win, because, according to him, knowing a language is a skill that makes a person better.

On the other hand, M5 views languages as a means of communication and of help. The example he gave comes from his personal experience. More specifically, M5 attends a school at which he learns the Greek language. As he mentioned, the teacher at that school speaks many languages such as French, Spanish, Italian, English and Greek, which is her mother language. M5 has observed that the teacher uses these languages during teaching and this helps students learn the Greek language.

M6 supports that knowing a language contributes to the improvement of one's life. In addition, M6 supports that languages are freedom. Speaking about her personal experience from Greece, M6 believes that when you know the official language of the host country you feel free whereas when you do not 'have' the host country's official language you are not free.

That is why M6 expressed that the best thing Greece could do for people who do not speak the Greek language would be to organize a setting at which people could come in contact with locals and speak in Greek.

\subsubsection{Language Rights}

The next theme that emerged from the semi-structured interviews was relevant to language rights. Participants were asked whether they know what language rights are. However, none of the participants knew what language rights are nor they referred to their right to use their mother languages. M1, who used to be student at Law and Gymnastics University, answered that if he had finished University he would have known. M5 mentioned that he did not know what language rights are and that he had never heard of the term.

To the same question M6 said that she has never read something relevant to language rights. When the researcher briefly explained what language rights represent, M6 laughed and said that even though she has never read something relevant to language rights her opinion is in accordance to the existing theory. In fact, she added that she has learnt these issues through her personal experience and not through studying.

\subsubsection{Linguistic Human Rights and the Use of Mother Languages in Greece}

Another question that participants were asked was relevant to language rights and the use of their mother languages in Greece. More specifically participants were asked whether they would prefer to use their mother language(s) more and for what purpose they would want to use their language(s) in Greece.

To the first question, about the use of their mother language(s) in Greece M1 immediately answered that he does not think that, even if he wanted, something like that could have been possible in Greece because politicians would not agree. Despite of that, talking about people who have Arabic as their mother language, M1 mentioned that it would be very helpful and it would facilitate Arabic-speaking people to be able to communicate in their mother language since they also might not speak Greek very much especially in Greece's official services.

In contrary, when M2 was asked whether he would like to use Urdu in Greece he answered that he prefers to speak in Greek rather than in Urdu in order to learn the Greek language better. However, when M2 was asked whether he would like to use Urdu in Greece in official services he supported that it would be good to have someone translating and helping people with mother languages other than Greek.

To the same question M3 answered that he had never thought of being able to use his mother language officially in Greece. Nevertheless, when M3 thought of it more he said that it would have been better to be able to use his mother language in settings such as the hospital. M4 answered in a similar way. More specifically he mentioned that it would be good to be able to use his language especially in public services in Greece. Nevertheless, M4 believes that this would be difficult and that since he knows the Greek language he uses it. As he explained, being able to use the mother language(s) in official services would be good for people who do not speak Greek.

To the question about the use of mother language(s) in Greece, M5 mentioned that he does no longer find it necessary because he has now learnt Greek and that he would find it very helpful in case he did not know Greek. Even though M5 believes that being able to use his mother language in Greek services does not make a difference for him, when the 
researcher mentioned language rights and their importance M5 said that being able to use the mother language(s) needs to be applied for everybody.

In her turn M6 expressed a disappointment about language rights in Greece by sighing. She repeatedly mentioned that she was not able to use Arabic at all when she firstly came in Greece and that it was like Arabic did not exist. In addition to her personal experience in Greece, M6 mentioned that she tried a lot to find a translation of the official papers in other languages and even though these papers were addressed to foreign people her efforts were unsuccessful.

Supporting her opinion, M6 referred to two examples from the Greek reality. The first example she used was from a salesman in Syntagma who had a sign writing "no speaking English". The second incident was from the airport in Thessaloniki. M6 described that a tourist had forgotten her watch in the control area and the employee, who did not speak English, could not explain to the tourist what had happened. To these two examples M6 added that she finds it unacceptable not to be able to communicate in the English language in the country that is the center of tourism and that is mostly known for tourism.

As far as mother languages are concerned M6 explained that she thinks that not being able to use the mother language(s) in Greece is very bad. Moreover, there are not many people who can read and write in Greek and this situation forces people to learn Greek even though they might not be able to do so due to lack of time.

In contrary to the previous, participants seem to think that the existence of their mother language(s) in the Greek television or newspapers is not necessary due to the internet. Even though M1 has not seen television in Arabic in three years, he mentioned that he does not mind because he can watch everything he wants in Arabic through the internet. M2 also believes that it is not necessary that his mother language is included in television or in newspapers in Greece since he can use the internet in order to do so. As with the previous two participants, M4 watches television in Urdu every day through the internet.

When it comes to television, at the time of the interview M6 was watching a Greek serial that was translated in Arabic on television. As she mentioned, M6 has subscribed in a private application that provides its clients with shows and series from different countries and it also has some shows and series translated in other languages.

\subsubsection{Suggestions on Linguistic Human Rights}

In the last part of the semi-structured interviews participants made suggestions about LHR and the use of mother languages in Greece. Participants referred to the importance of using their mother language(s) particularly in cases like the residence permit papers, the bills, the driving license examination, the University, the police, the court, the papers needed for working and the hospital.

More analytically, M1 talked about people who have Arabic as their mother language. He explained that it would be better for them if they could use Arabic at the services of the residence permit papers. The next example M1 used was about bills. According to him bills should be printed in people's mother languages in order for them to understand. The example he used was about Syrians who want to pay their bills but finding someone to translate the bill usually takes time. Thus, these people miss the deadlines and they pay more.

Except of the bills he also talked about the hospital. As he mentioned, there are people who would not understand Greek and who could not speak, too. This fact makes these people look for a private doctor who could speak in their mother language(s) and who would demand a lot of money. However, M1 believes that one Arabic speaking doctor in each public hospital would be enough and Arabic people would not have to pay much money in order to understand from what they suffer.

The hospital was also mentioned by M2. M2 supported that being able to use the mother language(s) at the hospital would be very good in contrary to what happens now when they (people from Pakistan) go there and do not speak nor understand. M3 also referred to the domain of health and said that the use of mother language(s) at the hospital would be better.

As M1, M2 and M3 said, M4 mentioned that the hospital is one of the services at which it is very important for an individual to be able to use and to communicate using his/her mother language(s). M6 seemed to agree with the use of mother language(s) in public hospitals and to that she added another dimension. According to M6, the situation slightly changed with refugees. More specifically M6 explained that there are currently some non-governmental organizationssuch as the KETHI (the research center for gender equality) which are responsible for refugees and which try to help people by sending translators to hospitals where needed.

Another example M1 used was about the driving license. As he mentioned it is difficult for Syrians to study and to learn the theory and the signs in Greek. M1 suggested that people should be able to use their mother languages for the exams and the theory and that their license would be edited in the country's official language. The example M1 mentioned was 
from Belgium where people have the option to read in Arabic and to take the license in French.

M1 also thinks that it is very important for an individual to be able to use his/her mother language(s) at University. More specifically, he believes that if people could use their mother languages at University they would be able to study and to graduate. After graduating they would work for Greece and Greece would benefit too.

Relevant to the previous, is M1's opinion about working papers. More analytically, M1 believes that if working papers were in people's mother language(s) Greece would benefit a lot and people would not work illegally.

Police is also a domain at which M1 believes that the use of the mother language(s) is important. He mentioned that not knowing what policemen ask for when talking to an individual who does not speak Greek might cause him/her fear, even if the policeman asks for something simple such as for the person's papers. For M6 police, together with the hospital, the paper services, and the bank, is also an important domain at which use of mother language(s) is very important.

Similar to that is the court. M1 believes that people must be able to use their mother language(s) in the court in order to understand, to participate in the procedure and not to be mere viewers. M6, just as M1, thinks that it is very important to have a translator who will explain to the suspect what is going on.

As far as the court is concerned, according to M6 the court is the only official setting at which the person has the ability to have a translator and M6 had been helping in translations years ago. In fact, as M6 explained, in the court there are lists with the telephone numbers and the names of people who can translate. The people who have the role of translator are informed about a trial and they get paid for their services.

When it comes to school, M1 suggested that it would be very good to have students' mother languages as lessons and that even the Greek students would benefit from that. However, he thinks that it is important not to force students to learn a language, like they do in Syria, but to leave students decide which languages to learn.

M4 also expressed his own point of view about schools. At first, he laughed and said that it is difficult to include Urdu in the Greek schools. However, when asked if he thought that for a Pakistan child it would be good to learn Urdu, as Urdu is his/her mother language, together with Greek M4, answered that this way it would be good to know both languages.

As far as education is concerned, M5 used an example from his personal experience from Germany. According to him, students in Germany have to learn their mother language(s) together with German. Moreover, he thought that this system could be adopted in Greece too with the employment of teachers who come from students' countries of origin. More specifically, M5 referred to a friend of his who is an Urdu teacher from Pakistan living in Greece and who could possibly teach students Urdu at a Greek school.

Equally important is teaching of mother language(s) for M6. Using the example of Sweden, M6 said that in Scandinavian countries teaching students' mother language is obligatory. She also thinks that this policy is very innovative and that it positively helps students evolve.

Except of these, M6 suggested that the use of mother language(s) at school would be very helpful for parents, too. As an example, she referred to an Egyptian whose children attend a public primary school. She explained that it is very important to somehow involve parents at school, to communicate with their children's teachers and that this could be done using parents mother language(s). To that M6 suggested that each school have a translator for the spoken languages in order to facilitate communication.

When asked about suggestions in order to improve LHR in Greece, M2 answered that it would be good to have Urdu in official papers. That would make him able to do everything on his own, without help, and to use his mother language. M6 also mentioned that in Sweden official papers exist in different languages.

Based on the case of Sweden, M6 suggested that it would be good to have official documents in different languages in Greece. That would be very helpful for the person who would understand what he/she is asked to do and who would know where and what he/she signs in each case. According to M6 having official documents in different languages is of particular importance for public services, the bank, the hospital, and other such services.

Being able to use his mother language for official services and papers in Greece is no longer necessary for M3. Nevertheless, M3 mentioned that he finds it good for a person to be able to use his/her mother language in official settings and that he would like to be able to use Urdu in official procedures, such as papers, in Greece.

Similar was the answer that M4 gave. More specifically, he mentioned that he does no longer need to use his mother language in Greek and that the embassy of Pakistan sends the official papers in Urdu. However, he thinks that for people who do not speak Greek -as it was the case with him when he first came in Greece and he did not know the language- it is good to be able to do the official procedures in their mother language(s). 
When asked for ideas in order to improve language rights in Greece, M5 suggested that it would be good to use French as an intermediate language. M5 suggested French because it is spoken by most Pakistani people and that it would facilitate official procedures.

\subsection{Discussion}

The first theme that emerged from the data analysis was relevant to participants' mother languages and maintenance of these languages in the host country. Kipp, Clyne and Pauwels (1995) referred to multiple factors that influence the maintenance of the mother language(s), such as the individual's age, gender, level of education, etc. According to Luo and Wiseman's (2000) research with Chinese immigrant children, the use of the mother language with friends and relatives is the most usual reason for language maintenance. In addition to that, the use of the mother language(s) at home is one of the major reasons for language maintenance (Hakuta \& D'Andrea, 1992).

As in Luo's and Wiseman's (2000) and Hakuta and D'Andrea (1992) researches, participants in this research mentioned that they only speak their mother language(s) with friends and members of their family, mostly at home. In other words, participants seem to maintain their mother language(s) with people who are close to them and in a familiar space, such as their home. However, in contrary to Kipp et al.'s (1995) research, all of the six participants, regardless of their age, their gender and their level of education, mentioned that they prefer to use the Greek language especially in public space and that they choose to speak their mother language(s) in few cases.

Except of participants' view on the use of the Greek language, the use of the host country's official language by immigrants is associated with different aspects. According to the Ethnic Diversity Survey that was conducted in Canada (2003), immigrants' use of the official languages relates to civic participation. The better the person speaks the official languages the more possibilities for joining groups and organizations he/she has. This means that good knowledge of the host country's languages contributes to a faster and better integration in the host country.

Except of that, the use of the mother language(s) when learning a second/foreign language has caused different reactions. On the one hand there are scholars, such as Cummins (1983), who support that skills from the mother language(s) are transferred when learning a second/foreign language and contribute to better and faster acquisition of the target language. On the other hand, there are numerous scholars who view mother language(s) as an obstacle in the acquisition of the second/foreign language. Fries (1945) was one of the first scholars who supported that the individual's mother language(s) poses many problems when learning a second/foreign language. A few years later, Lado (1957) attributed the failure of learning a second/foreign language to the use of mother language(s) by the learners. Grabe and Kaplan (1989) explained that the differences between the mother language(s) and the target language prevent the learner from effectively learning the target language.

From the data analysis it resulted that participants have different mother languages. In accordance to the existing researches, participants mentioned that they mostly use their mother language(s) at home, mainly when they talk to friends or family. In contrary to that, participants said that they prefer to use Greek, the host country's official language, when they are in public space because they believe that this will help them learn the language better. The fact that participants choose to use the country's official language in public space confirms the view for negative rights (Wright, 2007) according to which minority languages are only used in the individual's private space with people with similar mother language(s).

Another major theme that emerged from the interviews is relevant to participants' view on languages. From their answers, participants connect languages to money, to helping, to freedom, to personal progress. In general, participants supported that the individual benefits a lot from learning a second/foreign language. All participants seemed familiar with the idea of learning a new language. They all speak more than two languages and they use them for different reasons and in different circumstances. Specifically, M1 mentioned that the more languages an individual knows the better he/she is. Similar to that, M6 supported that knowing a language improves the individual's life. The same view about languages was also supported by numerous scholars, such as Paradowski (2011), Diamond (2010), Komorowska (2010), Kroll and Dussias (2017) who believe that the individual benefits a lot from knowing many languages.

Language's connection to freedom was an important issue that emerged from the interviews. As M6 mentioned, language is like freedom; if you know the language and if you can express yourself in this language you feel free. M6 explained that not knowing enough vocabulary in the host country's official language prevents the person from speaking the language and thus prevents him/her from being free. The relation between freedom and language is also supported by Shohami (2006). More specifically, she mentions that the fact that people's ability to make linguistic choices indicates their degree of freedom. This means that as M6 explained, limited knowledge of a language equals limited sense of freedom.

Taking into consideration the relation between language and freedom, Shohami (2006) indicated that "an expanded 
view of LP (Language Policy) requires a broader view of language itself [...] towards freedom of expression” (p. 1). However, in spite of the importance of language policy, governments view languages as tools which contribute to "manipulation" of people in different domains such as the social, the economic and the educational domain. In other words, instead of promoting the sense of freedom that languages give to people, language policies perpetuate discriminative behaviors and power relations.

Participants' sayings together with M6's view on language bring human rights and Linguistic Human Rights to the fore. There are multiple organizations and sites that defend human rights and that try to inform immigrants on their rights. However, in spite of the efforts, there is still a large number of immigrants that do not know their rights. Merry (2006) referred to a general lack of knowledge that is related to human rights. In addition to that, Simmons (2009) identifies an important gap between theoretical and practical knowledge of rights. Simmons' view is confirmed by M6's saying that even though she had never read about language rights she already believes on language rights from her personal experience. In general, the present research is in accordance with the above scholars' view since none of the participants knew about language rights. In fact, half of the participants mentioned that they had never thought that being able to use their mother language(s) in official settings in the host country would be their right.

Focusing on the case of Greek, LHR and language rights in general seem to be in an early stage. According to the six participants, Greek and in some cases, English seem to be the languages used in services and in official settings in Greece. The two examples that M6 mentioned in her interview enhance the above view about LHR and language rights in Greece. Some of the participants mentioned that since they have learnt the Greek language they do not need to use their mother language(s) in official Greek settings.

According to Castiglione and Longman (2007) "language is seen as a resource that is constitutive of human autonomy and freedom" (p. 63). The same view is supported by to Noels, Pelletier, Clément and Vallerant (2000). These scholars mentioned that the individual's will to develop linguistic skills in the host country's language is connected to the individual's positive self-image, to feeling of freedom and autonomy in the host country. Participants of this research confirmed the aforementioned views by supporting that being able to use their mother language(s) to official settings -such as the hospital, the police station, the court and the social services- would feel more autonomous, they would be more visible and they would be able to defend their rights.

To that M4 and M6 added that being able to use their mother language(s) in official settings would make many people feel relieved. As they explained, immigrants who come to Greece have working as their priority. This means that there is not enough time for them to learn the host country's official language and few of these people know how to read and write in Greek. Thus, being able to use their mother language(s) would enable them to do more without having to miss a chance to work.

In spite of the importance that the use of mother language has, the participants explained that the situation is different in Greece. People cannot use their mother language(s) in official settings and they are somehow forced to learn Greek. In fact some participants mentioned that since they have learnt Greek they do not need to use their mother language(s) in such settings any more. This policy contributes to the "reducing of the functional load of minority languages in the public domain" (Pandharipande, 2002, p. 218) and increases the status of Greek as the country's official language.

Participants seemed to be aware of the existing monolingual language policies in Greece and expressed their doubt towards multilingual practices in the country. Indicatively, M1 mentioned that politicians would not agree with a multilingual policy. On the other hand, M3 said that he had never even thought of being able to use his mother language in official settings and M5 wondered about the difficulties and the challenges towards multilingual changes in Greece. The challenges that applying multilingual policies has in Greece as well as the difficulties that participants faced when they first came in the country seemed to be some of the reasons why participants learnt the Greek language. In fact, when asked if they would like to be able to use their mother languages in official settings in Greece, M4 answered that he knows that something like that is difficult and that is why he speaks in Greek.

In general participants referred to the hospital, the school, the police station, the court and other governmental services as central institutions where the use of people's mother language(s) would be helpful. As far as the health domain is concerned, Szczepura's (2005) research indicated the inequities that exist and the linguistic barrier that minorities face. The language barrier was characterized as a "major obstacle" for minorities in healthcare by Gerrish et al. (2004, p. 407). The fact that in the present research all participants referred to the necessity of using mother languages in hospitals confirms the importance of the language barrier in this domain. According to participants it would be very helpful to have one doctor in each hospital who could speak the patient's mother language. That would help people understand their health problem in the public hospitals without having to spend big amounts of money on private doctors.

The police station and the court were the next institutions to which participants referred. Starting from simple 
commands, such as showing the residence permit papers, to more complex procedures, such as the court, language can be a very important factor. Madoc-Jones and Parry's (2012) research on the justice system in Whales indicated that the language barrier is used in many cases against the minority language speaker. Similar findings are included in Valero-Garcés and Martin's (2008) book. As M1 mentioned it is important to include different mother language(s) in the court because that will help minority language speakers participate and be aware of what is happening. As M1 explained, involving minority languages in such settings might prevent the minority language speaker from anxiety, fear and will to escape.

At this point it is important to mention the reference that M6 did to the changes that have been applied after the arrival of refugees in 2015. According to her, refugees' arrival activated many organizations and institutions, such as the

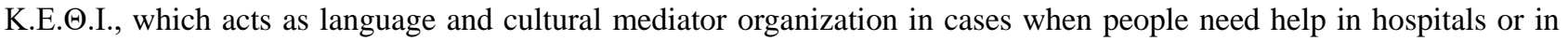
the court. M6 shared her experience and mentioned that she worked as a translator in the court and in the hospital helping women from Syria. As she mentioned, such modifications are very important and might constitute to a change in the existing situation.

Equally important to the previous is the domain of education. Participants of this research supported that it would be very good for all minority students to be able to learn their mother language(s) together with the official language(s) at school. Including minority languages at public schools would also be helpful for minority students' parents, too. According to M6 being able to communicate in their mother language(s) would help minority students' parents get informed about the educational setting and the educational procedures and it would give them a sense of participating. To the previous, M1 added the dimension of tertiary education. As he mentioned, Greece will benefit from involving minority languages in Universities and minority language speakers will have the chance to study and work for Greece.

The multiple advantages of including minority languages in education are supported by numerous scholars. Minghua (2002) in her psycholinguistic study insisted on the positive effects that involving students' mother language(s) has learning a second/foreign language. Through his researches, Cummins (2001) highlighted the importance that students' mother languages have for students' self-esteem and progress in the target language. Moreover, Thomas and Collier (2002) found that students, who were capable of using their mother language effectively, did better in the target language.

After expressing their opinions on language rights in Greece, participants referred to examples that were relevant to LHR, from other countries. M1 used the example of Belgium. As he mentioned, Arabic speaking people in Belgium have the opportunity to use their mother language in the driving license, in the papers they need for working and in the hospitals.

M5 referred to an example from Germany. According to him, there are schools in Germany at which students have to learn their mother languages together with Germany, which is the country's official language.

M6 described a similar example from Sweden. According to her, in Sweden it is obligatory for students to learn their mother language(s) together with Swedish. Except of the school M6 referred to official documents that exist in different languages.

In contrary to the examples that M1, M5 and M6 mentioned, the existing language policies in Greece seem to leave minority languages behind. As far as education is concerned, Greece's educational system is based on the Conventions and the Treaties to which it has signed. More specifically, following the UDHR (1948), Greece has enacted that the first nine years of education are compulsory and free, and that education aims to "the full development of the human personality and the sense of its dignity", with a focus on human rights (International Covenant on Economic, Social and Cultural Rights, 1966). When it comes to LHR in the Greek educational system, students' mother languages are not included in the existing curricula even though the Convention against Discrimination in Education (1960) refers to "teaching of their (students') own language".

On the other hand, based on M6's sayings, the Supreme Civil and Criminal Court of Greece, following the fourteenth article of the International Covenant on Civil and Political Rights (1966), gives people the opportunity to "be informed promptly and in detail in a language which he understands [...]" and to "have free assistance of an interpreter if he cannot understand or speak the language used in the court". This means that in this case, Language Human Rights are respected and protected.

Linguistic Human Rights in relation to the media in Greece were also discussed in the semi-structures interviews. Participants mentioned that in Athens, the city where they are staying, they can only watch television or listen to the radio in their mother languages through the internet. As they mentioned, there are no channels in their mother languages, neither on television nor on the radio. This lack of channels is contrary to the ninth Article of the Framework Convention for the Protection of National Minorities (1988) according to which Greece should "recognize that the right 
to freedom of expression of every person belonging to a national minority includes freedom to hold opinions and to receive and impart information and ideas in the minority language [... $]$ " (p. 4).

From the above it results that the existing language policies that are in force in Greece partly respond to the Conventions and the Treaties to which Greece has signed. Even though Greece has signed multiple Conventions and Treaties that refer to language rights, participants supported that the existing policies prevent them from using their mother languages, especially in the official public services.

\section{Recommendations for the Promotion of Multilingualism in Greece}

Participants in the present research supported that they rarely have the opportunity to use their mother language(s) in official services and settings in Greece. This means that in most cases these participants do not have access to some major human rights due to the language barrier. The present sub-section includes indicative suggestions that are thought to promote multilingualism in Greece.

The first suggestions towards multilingualism focus on education. When it comes to public schools, the European Commission (2019) reports that the majority of the teaching staff does not have the skills to respond to the needs of multilingual students and immigrant students' languages remain invisible. Following the example of countries to which participants referred, it would be advisable to invest on multilingual education through appropriately educated staff. Another suggestion would be to include students' mother language(s) in the educational curriculum. Students' mother languages could be taught by teachers-native speakers of each language.

In order to support multilingualism at school, appropriate teaching material is required. A suggestion concerning educational material would be to encourage and/or to sponsor the production of educational material by native-speaking teachers. Another suggestion would be the promotion of cooperation between countries. Projects that support education of the corresponding language in Greece could contribute to better results towards multilingual education.

However, all the above suggestions in education would be different if students were given appropriate motivation to attend courses of their mother language(s) in Greece. As mentioned by Van Dongera et al. (2017) a country that strictly follows monolingual practices has negative effects on education in students' mother languages. In other words, when students feel that their mother language(s) is/are not affirmed or that their mother language are useless in Greece students lose their interest and refuse to invest in their mother language(s).

An idea for motivating students in order to invest on their mother language(s) would be to provide them with opportunities to use their mother language(s) in the educational system. If students could take exams in their mother language(s) or if there were institutions and academic programs in Greece where students could use their mother language(s) then they would be motivated to study their mother language(s). Motivation does not only refer to students; it also refers to their parents. In order to support learning of a student's mother language(s) in Greece his/her parents should feel that their children benefit from learning their mother language(s).

The above suggestions call for cooperation between different countries and for an open exchange of practices concerning multilingual education. This dialogue could lead to major changes in the Greek educational system that would have positive effects in multiple levels. However, changes do not only concern education. In fact, education affects and is affected by government's policies in general. This means that multilingualism calls for appropriate modifications in the existing language policies in Greece.

The first suggestion towards multilingualism concerns hospitals. It would be advisable to have a network of doctors and/or interpreters who could help patients with different mother languages. Being able to use their mother language(s) in hospitals would make patients feel more secure and it would also contribute to their right to access public health. In contrary to the existing situation in Greece where some hospitals cooperate with interpreters from NGOs, having staff that could help patients communicate at any moment would promote multilingualism and would also be in favor of human rights.

When it comes to languages in the public sphere, Albi (2003) uses the eleventh Article of the Framework Convention according to which "the state should display traditional local names, street names and other topographical indications [...] also in the minority language [...]" (p. 160). Based on this Article, governments should include minority languages in public space, such as in public signs, making these languages more visible.

Despite of the numerous suggestions and the binding Conventions that refer to language rights states are responsible for the implementation of corresponding policies. As Albi (2003) mentions "the state has the primary obligation to implement the general guidelines enshrined in international instruments to guarantee the effective protection of the minority rights under the international law" (p. 161). This means that through appropriate language policies, minority languages could be promoted and LHR could be supported. 


\section{Conclusion}

Languages are a very important issue that is closely related to human rights. In spite of languages' importance, there are many cases at which it seems that the laws that refer to languages are not abided. As far as immigrants in Greece are concerned, research shows that information is in most cases not provided in a language that they know or understand (Ghandour-Demiri, 2017). In these cases, minority languages are underestimated and applicants' rights are violated.

The present research aimed to explore adult immigrants' perspective, as minority language speakers, on the existing language policies in Greece with a focus on LHR. Participants used examples from their personal experience in regards to the use of languages Greece. As they explained, they could not use their mother languages in public services and in official settings, such as the hospitals, the police, the schools. One of the participants characteristically mentioned that in Greece "it was like Arabic did not exist".

The monolingual policy that is followed in Greece, prevents minority language speakers from exercising their language rights and, in many cases, their LHR are violated. Such phenomena strengthen language and communication barriers. Moreover, participants' ignorance of LHR, makes the existing language policies seem less discriminative and contributes to a covering of the policies' underlying prejudices, affecting the individual's life and identity in multiple levels. Data from the present research confirmed that the monolingual policies have detrimental effect on immigrants' lives. More specifically, participants of this research explained that they feel more vulnerable, insecure and experience social exclusion due to the language barrier.

To conclude, even though there is "scientific evidence" (Skutnabb-Kangas, 2000, p. 665) in favor of multilingualism and even though monolingualism leads to violations of LHR, the existing language policies in Greece seem to insist on monolingualism. Even though Greece has signed multiple Conventions and Treaties that refer to language rights, the existing policies seem to prevent immigrants from using their mother languages, especially in the official public services. Participants mentioned that being able to use their mother language(s) to official settings -such as the hospital, the police station, the court and the social services- would make them feel more autonomous, less vulnerable and socially excluded, they would be more visible and they would be able to defend their rights. Thus, protecting and promoting language rights and LHR is, now more than ever, of major importance, not only for society but for the individual, too.

\section{References}

Albi, K. (2003). The Right to Use Minority Languages in the Public Sphere: Evaluation of Estonian Legislation in Light of the International Standards. Juridica International, 8, 151-161.

Allardt, E. (1984). What constitutes a language minority? Journal of Multilingual and Multicultural Development, 5(3-4). https://doi.org/10.1080/01434632.1984.9994151

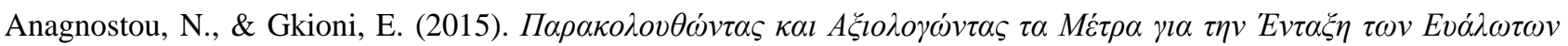

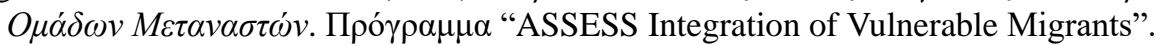

Baldauf, R. B. Jr. (2006). Rearticulating the Case for Micro Language Planning in a Language Ecology Context. Current Issues in Language Planning, 7(2\&3), 147-170. https://doi.org/10.2167/cilp092.0

Berelson, B. (1952). Content Analysis in Communication Research. New York: Free Press.

Berelson, B. (1971). Content Analysis in Communication Research. New York: Hafner Publishing Company.

Browne, N., \& Donnelly, D. (2013). Making human rights matter to the marginalized. Retrieved from: https://www.opendemocracy.net/en/openglobalrights-openpage/making-human-rights-matter-to-marginalised/

Castiglione, D., \& Longman, C. (2007). The Language Question in Europe and Diverse Societies: Political, Legal and Social Perspectives. United States of America: Hart Publishing.

Cooper, R. L. (1989). Language planning and social change. Cambridge: Cambridge University Press.

Council of Europe (1992). European Charter for Regional or Minority Languages. Retrieved from https://www.cornwall.gov.uk/media/21486313/ecrml.pdf

Cummins, J. (1983). Language proficiency, biliteracy and French immersion. Canadian Journal of Education, 8(2), 117-138. https://doi.org/10.2307/1494722

Cummins, J. (2001). Negotiating identities: Education for empowerment in a diverse society (2nd ed). Los Angeles: California Association for Bilingual Education.

David, M. K., Cavallaro, F., \& Coluzzi, P. (2009). Language Policies - Impact on Language Maintenance and Teaching: Focus on Malaysia, Singapore, Brunei and The Philippines. The Linguistics Journal, Special Issue, 155-191. 
Retrieved

from https://www.researchgate.net/publication/287311128_Language_Policies_-_Impact_on_Language_Maintenance_a nd_Teaching_Focus_on_Malaysia_Singapore_Brunei_and_the_Philippines_1

Dendrinos, B. (2007). Language Issues and Language Policies in Greece. In G. Stickel (Ed.), National and European Language Policies, pp. 53-69. Frankfurt, Berlin, Bern, Bruxelles, New York, Oxford, Wien: Peter Lang.

Dendrinos, B., \& Theodoropoulou, M. (2008). Language Issues and Language Policies in Greece. National and European Language Policies, 53-69.

Derose, K. P., Escarce, J. J., \& Lurie, N. (2007). Immigrants and Health Care: Sources of Vulnerability. Health Affairs, 26(5), 1258-1268. https://doi.org/10.1377/hlthaff.26.5.1258

Diamond, J. (2010). The benefits of multilingualism. Science, 330, 332-333. https://doi.org/10.1126/science.1195067

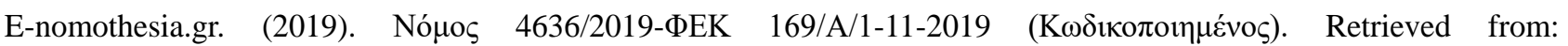
https://www.e-nomothesia.gr/kat-allodapoi/prosphuges-politiko-asulo/nomos-4636-2019-phek-169a-1-11-2019.html.

European Agency for Fundamental Rights \& Council of Europe. (2015). Handbook on European law relating to asylum, borders and migration. Belgium: Publications Office of the European Union. Retrieved from: https://www.europarl.europa.eu/greece/resource/static/files/handbook-on-european-law-relating-to-asylum--border s-and-immigration.pdf

Gerrish, K., Chau, R., Sobowale, A., \& Birks, E. (2004). Bridging the language barrier: the use of interpreters in primary care nursing. Health \& Social Care in Community, 12(5), 407-413. https://doi.org/10.1111/j.1365-2524.2004.00510.x

Fettes, M. (1997). Language planning and education. In R. Wodak and D. Corson (Eds.), Language Policy and Political Issues in Education (pp. 13-22). Dordrecht, The Netherlands: Kluwer Academic.

Fries, C. (1945). Teaching and learning English as a foreign language. Ann Arbor: University of Michigan Press.

Ghandour-Demiri, N. (2017). Language \& Comprehension Barriers in Greece's Migration Crisis. A Study on the Multitude of Languages and Comprehension of Material Provided to Refugees and Migrants in Greece.

Grabe, W., \& Kaplan, R. (1989). Writing a second language: Contrastive rhetoric. In D. Johnson and D. Roen (Eds.), Richness in writing: Empowering ESL students, (pp. 263 -283). New York: Longman.

Grenoble, L., \& Singerman, A. D. (2017). Minority Languages. Oxford Bibliographies.

Grin, F. (2000). Evaluating policy measures for minority languages in Europe: Towards effective, cost-effective and democratic implementation. ECMI Report 6, October 2000. Flensburg: ECMI.

Gropas, R., \& Triantafyllidou, A. (2011). Greek education policy and the challenge of migration: an 'intercultural' view of assimilation. Race Ethnicity and Education, 14(3), 399-419. https://doi.org/10.1080/13613324.2010.543394

Goundar, P. R. (2017). The Characteristics of Language Policy and Planning Research: An Overview. In X. Jiang (Ed.), Sociolinguistics - Interdisciplinary Perspectives. https://doi.org/10.5772/intechopen.68152

Hakuta, K., \& D'Andrea, D. (1992). Some properties of bilingual maintenance and loss in Mexican background high-school students. Applied Linguistics, 13(1), 72-99. https://doi.org/10.1093/applin/13.1.72

Haugen, E. (1953). The Norwegian Language in America: A study in Bilingual Behavior. Bloomington: Indiana University Press. https://doi.org/10.9783/9781512820522

Human Rights Watch. (2019). Greece. Events of 2018 - Part of the EU Chapter. Retrieved from https://www.hrw.org/world-report/2019/country-chapters/greece

International Migration Law. (2019). Glossary on Migration. Geneva: International Organization of Migration (IOM). Retrieved from https://publications.iom.int/system/files/pdf/iml_34_glossary.pdf

Javadi, M., \& Zarea, M. (2016). Understanding Thematic Analysis and its Pitfalls. Journal Of Client Care, 1(1), 33-39. https://doi.org/10.15412/J.JCC.02010107

Kaplan, R. B., \& Baldauf, R. B. (1997). Language Planning from Practice to Theory. Great Britain: Multilingual Matters.

Kipp, S., Clyne, M., \& Pauwels, A. (1995). Immigration and Australia's Language Resources. Canberra: Australian Government Publishing Service.

Kjaerum, M. (2005). Human Rights for Immigrants and Immigrants on Human Rights. In E. Guild and J. van Selm (Eds.), International Migration and Security, pp. 51-64. New York: Routledge. 
Kloss, H. (1969). Research Possibilities on Group Bilingualism: A Report. Quebec: International Centre for Research on Bilingualism.

Komorowska, H. (2011). Issues in Promoting Multilingualism. Teaching-Learning-Assessing. Warsaw: Frse.

Kroll, J., \& Dussias, P. (2017).The Benefits of Multilingualism to the Personal and Professional Development of Residents of the US. Foreign Language Annals, 50(3). https://doi.org/10.1111/flan.12271

Kymlicka, W., \& Patten, A. (2003). Language Rights and Political Theory. New York: Oxford University Press. https://doi.org/10.1017/S0267190503000163

Lado, R. (1957). Linguistics across cultures. Ann Arbor: University of Michigan Press.

Larsen-Freeman, D. (2018). Resonances: Second language development and Language planning and policy from a complexity theory perspective. In M. Siiner, F. M. Hult and T. Kupisch (Eds.), Language policy and language acquisition planning (pp. 203-217). Switzerland: Springer. https://doi.org/10.1007/978-3-319-75963-0_12

Leibowitz, B., Adendorff, H., Daniels, S., Loots, A., Nakasa, S., Ngxabazi, N., Van der Merwe, A. \& Van Deventer, I. (2005). The Relationship Between Identity, Language and Teaching and Learning in Higher Education in South Africa. Per Linguam, 21(2), 23-37. https://doi.org/10.5785/21-2-74

Lo Bianco, J. (2010). Language Policy and Planning. In N. H. Hornberger and S. L. McKay (Eds.), New Perspectives on Language Education: Sociolinguistics and Language Education (pp. 143-174). Bristol, Buffalo, Toronto: Multilingual Matters. https://doi.org/10.21832/9781847692849-008

Luo, S. H., \& Wiseman, R. L. (2000). Ethnic Language Maintenance among Chinese Children in the United States. International Journal of Intercultural Relations, 24(3), 307-324. https://doi.org/10.1016/S0147-1767(00)00003-1

Madoc-Jones, I., \& Parry, O. (2012). 'It's Always English in the Cop Shop': Accounts of Minority Language Use in the Criminal Justice System in Wales. The Howard Journal of Criminal Justice, 52(1), 91-107. https://doi.org/10.1111/j.1468-2311.2012.00726.x

Maguire, M., \& Delahunt, B. (2017). Doing a Thematic Analysis: A Step-byStep Guide for Learning and Teaching Scholars. All Ireland Journal of Teaching and Learning in Higher Education (AISHE-J), 3, 3351-3364.

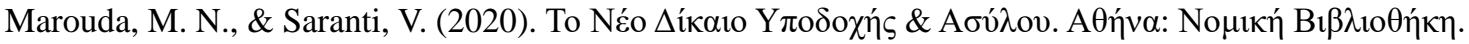

McGroarty, M. (1997). Language Policy in the USA. In W. Eggington and H. Wren (Eds.), Language Policy, (pp. 1-29). Amsterdam: Benjamins. https://doi.org/10.1075/z.83.09mcg

McNelly, C. A. (2015). Language Learning Policy through the Lens of Language as a Problem, as a Right, and as a Resource. NABE Journal of Research and Practice, 6, 5-26. https://doi.org/10.1080/26390043.2015.12067782

Merry, S. E. (2006). Human Rights and Transnational Culture: Regulating Gender Violence through Global Law. Osgoode Hall Law Journal, 44(1), 53-75.

Minghua, G. (2002). Effects of Mother Tongue in Foreign Language Classes. Foreign Languages and their Teaching.

Nagpal, J., \& Nicoladis, E. (2010). Positive attitudes are not enough: Minority language survival in the Canadian prairies. Journal of International Communication, 24.

Nkopuruk, I. (2018). Status Planning, Corpus Planning and Acquisition Planning: Detailed.

Discourse with Examples from Two African Countries - Tanzania and Bokina Faso. Retrieved from: https://www.researchgate.net/publication/327541764_Status_Planning_Corpus_Planning_and_Acquisition_Planni ng_Detailed_Discourse_with_Examples_from_Two_African_Countries-Tanzania_and_Bokina_Faso.

Noels, K., Pelletier, L., Clément, R., \& Vallerand, R. (2000). Why Are You Learning a Second Language? Motivational Orientations and Self-Determination Theory. Language Learning, 50(S1), 57-85. https://doi.org/10.1111/0023-8333.00111

Ochs, E., \& Bambi, S. (1995). The impact of language socialization on language development. In P. Fletchera and B. MacWhinney (Eds.), The handbook of child language, pp. 73-94. Oxford: Blackwell. https://doi.org/10.1111/b.9780631203124.1996.00004.x

Pandharipande, R. (2002). Minority Matters: Issues in Minority Languages in India. IJMS: International Journal on Multicultural Societies, 4(2), 213-234.

Paradowski, M. (2011). Multilingualism. Assessing Benefits. In H. Komorowska (Ed.), Issues in Promoting Multilingualism. Teaching-Learning-Assessing. Warsaw: Frse.

Phillipson, R., \& Skutnabb-Kangas, T. (2017). Linguistic rights and wrongs. In T. Skutnabb-Kangas and R. Phillipson 
(Eds.), Language Rights, (2nd ed.), 456-464. London: Routledge.

Phillipson, R., Rannut, M., \& Skutnabb-Kangas, T. (1994). Introduction. In R. Phillipson and T. Skutnabb-Kangas (Eds.), Linguistic Human Rights. Overcoming Linguistic Discrimination. Berlin: Mouton de Gruyter. https://doi.org/10.1515/9783110866391

Piller, I., \& Takahashi, K. (2010). Language, migration and human rights. In R. Wodak, B. Johnson and P. Kerswill (Eds.), Sage Handbook of Sociolinguistics, pp. 573-587. London: Sage.

Ritter, E. H. (2019). Human rights treaties benefit the world's most oppressed. Retrieved from https://www.newswise.com/politics/human-rights-treaties-benefit-the-world-s-most-oppressed/?page=1\&search[sta tus]=3\&search[sort]=date+desc\&search[channel_id]=22\&category=\#!

Russak, S. (2016). Do inclusion practices for pupils with special educational needs in the English as a foreign language class in Israel reflect inclusion laws and language policy requirements? International Journal of Inclusive Education, 20(11), 1188-1203. https://doi.org/10.1080/13603116.2016.1155666

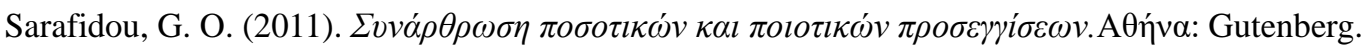

Santos Rovira J. M. (2015). Attitudes Towards State Languages versus Minority Languages in the Contemporary World: The Case of Catalan in Sardinia. New Diversities, 17(2), 163-176.

Shohami, E. (2006). Language Policy: Hidden agendas and new approaches. New York: Routledge. https://doi.org/10.4324/9780203387962

Simmons, B. A. (2009). Mobilizing for Human Rights: International Law in Domestic Politics. United States of America: Cambridge University Press. https://doi.org/10.1017/CBO9780511811340

Skutnabb-Kangas, T. (2000). Linguistic Genocide in Education - or Worldwide Diversity and Human Rights? Mahwah: Lawrence Erlbaum.

Skutnabb-Kangas, T. (2008). Linguistic Genocide in Education - or Worldwide Diversity and Human Rights. Delhi: Orient Blackswan.

Skutnabb-Kangas, T. (2008). Human rights and language policy in education. In S. May and N. H. Hornberger (Eds). Language Policy and Political Issues in Education, Volume 1. Encyclopedia of language and education, (2nd ed.), pp. 107-119. New York: Springer. https://doi.org/10.1007/978-0-387-30424-3_9

Skutnabb-Kangas, T. (2012). The Role of Linguistic Human Rights in Language Policy and Planning. C. A. Chapelle (Ed.), The Encyclopedia of Applied Linguistics. https://doi.org/10.1002/9781405198431.wbeal1026

Skutnabb-Kangas, T., \& May, S. (2017). Linguistic Human Rights in Education. In T. L. McCarty and S. May (Eds.), Language Policy and Political Issues in Education, pp. 125-141. https://doi.org/10.1007/978-3-319-02344-1_10

Szoszkiewicz, L. (2017). Linguistic Human Rights in Education. Przegląd Prawniczy Uniwersytetu im. Adama Mickiewicza, 7(1). https://doi.org/10.14746/ppuam.2017.7.07

Terdiman, R. (1985). Discourse/Counter-discourse. New York: Cornell University Press.

Thomas, W. P., \& Collier, V. P. (2002). A national study of school effectiveness for language minority students' long-term academic achievement in Santa Cruz. California: Center for Research on Education, Diversity and Excellence, University of California-Santa Cruz.

Tollefson, J. W. (1991). Planning Language, Planning Inequality. New York: Longman.

Triandafyllidou, A. (2000). 'Racists? Us? Are you Joking?' The Discourse of Social Exclusion of Immigrants in Greece and Italy. In R. King, G. Lazaridis and C. Tsardanidis (Eds.), Eldorado or Fortress? Migration in Southern Europe, pp. 186-206. Great Britain: Macmillan Press Limited. https://doi.org/10.1057/9780333982525

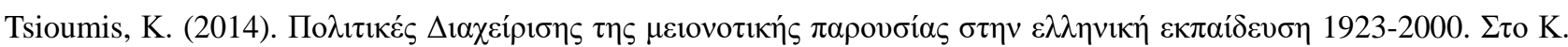

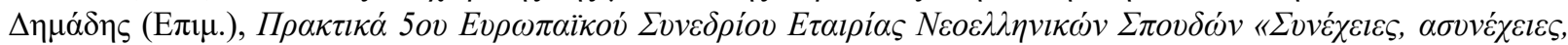

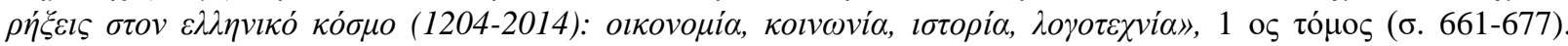

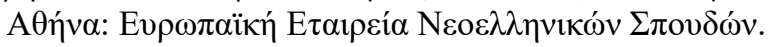

UNCHR. (2016). Men, Women and Children- Trends of Arrivals in Greece, June 2015- 16 January 2016. Retrieved from https://data2.unhcr.org/en/documents/download/46726

United Nations. (1945). Charter of the United Nations and Statute of the International Court of Justice. Retrieved from https://www.un.org/en/charter-united-nations/ 
United Nations. (1948). Universal Declaration of Human Rights. Retrieved from https://www.un.org/en/universal-declaration-human-rights/

Valero-Garcés, C., \& Martin, A. (2008). Crossing Borders in Community Interpreting: Definitions and dilemmas. The Netherlands: John Benjamins Publishing. https://doi.org/10.1075/btl.76

Van Dongera, R., Van Der Meer, C., \& Sterk, R. (2017). Research for CULT-Committee -Minority Languages and education: best practices and pitfalls. Brussels: European Parliament, Policy Department for Structural and Cohesion Policies.

Weinreich, U. (1953). Languages in Contact: French, German and Romansh in twentieth-century Switzerland. Amsterdam, Philadelphia: John Benjamins Publishing Company.

Wiley, T. G. (2015). Language policy and planning in education. The handbook of bilingual and multilingual education, 164-184. https://doi.org/10.1002/9781118533406.ch10

Williams, S. M. (1998). Voice, Trust and Memory. Marginalized Groups and the Failings of Liberal Representation. New Jersey: Princeton University Press.

Wright, S. (2007). The Right to Speak One's Own Language: Reflections on Theory and Practice. Language Policy, 6(2), 203-224. https://doi.org/10.1007/s10993-007-9050-y

Yong, L., Poh, M. K., \& Xin, Z. L. (2016). Language Policy and Planning (LPP) for English in Malaysian Education System in the 21st Century. Journal of English Language and Literature, 6(2), 455-463.

\section{Copyrights}

Copyright for this article is retained by the author(s), with first publication rights granted to the journal.

This is an open-access article distributed under the terms and conditions of the Creative Commons Attribution license (http://creativecommons.org/licenses/by/4.0/). 